\title{
Assessment of Sustainable Development of the Region's Innovation System Based on the Concept of the Triple Helix Theory
}

\author{
Nikolay Egorov ${ }^{1, *}$, Grigoriy Kovrov ${ }^{1}$, and Mikhail Solomonov ${ }^{2}$ \\ ${ }^{1}$ Scientific-Research Institute of Regional Economy of the North "M.K. Ammosov North-Eastern \\ Federal University", Yakutsk, Russia \\ ${ }^{2}$ Federal Research Centre "The Yakut Scientific Centre of the Siberian Branch of the Russian \\ Academy of Sciences", Yakutsk, Russia
}

\begin{abstract}
The article is devoted to the methodological aspects of assessing the sustainability of the regional innovation system and assessing the contribution of the triad participants (education / science, business, government) to the overall region innovative development based on the Triple Helix model. The system of indicators has been determined, which allows to study the region innovative development as a whole and separately pursuant to the blocks of indicators of the triad. Integral rating assessments of the innovative development of the northern regions of Russia of the resource type for the period from 2010-2019 were performed, on the basis of which the levels of innovative sustainability of the regions were calculated and the shares of the contribution of the triad participants in the overall region innovative developmental economy were determined. The authors believe that the proposed methodological approach (algorithm) based on the Triple Helix model adequately solves the assessment of the level of sustainability of the innovative development of regions and the assessment of the contribution of the Triad participants to the overall region innovative development. In order to identify the strengths and weaknesses of the activities of the participants of the triad, innovative profiles of the regions have been built, which allow the executive bodies of local government to make appropriate regulatory and managerial decisions aimed at improving the weak positions of the activities of the participants in the triad. The main advantages of using this method include the simplicity of performing numerical calculations based on the standard Microsoft Excel platform, the use of official statistics that exclude the effect of subjectivity arising from the use of various weight coefficients. The obtained study results may be used by regional authorities to adjust the existing program documents in the field of innovation policy, as well as by various economic and social actors for monitoring and predictive assessment of the innovative development of their industry.
\end{abstract}

\section{Introduction}

\footnotetext{
* Corresponding author: ene01@yandex.ru
} 
One of the most important problems in the development of the country is to ensure sustainable development of the economy as a whole and its components. In Russia, the main tasks for a gradual transition to sustainable development, ensuring the solution of social-and-economic problems and problems of preserving a favorable environment and natural resource potential in order to meet the needs of present and future generations of people, are defined by the regulatory document "On the concept of the transition of the Russian Federation to sustainable development" [1].

Currently, there are many scientific works on the topic of sustainable economic development of the region [ref., for instance, 2-5]. The very concept of "sustainable development" was formulated in 1987 in the report of the UN World Commission on Environment and Development "Our Common Future", known as the G. Brundtland's report [6]. Pursuant to this report, sustainable development is development in which society meets the needs of the present and does not jeopardize the ability of future generations to meet their needs. Sustainable development is achieved as a result of the development of three interrelated system-forming factors: economic, social and environmental.

The sustainable development of the country's economy largely depends on the efficiency of the functioning of the national innovation system and, accordingly, on the sustainable development of the regional innovation system (RIS). The innovation stability of the regional social-and-economic system should be understood as the ability of the system to generate the creation of intellectual property objects for a certain period of time with their subsequent commercialization in the manufacturing sector in order to significantly change the structure of industry and develop production of a new technological order $[7,8]$.

If we consider the sustainable development of RIS as a result of effective interaction between the participants in the innovation process based on the Triple Helix model $[9,10]$, then the study of the influence of the scientific and educational complex, business and the state in the overall innovative development of an economic entity becomes an urgent scientific task.

In this regard, methodological and methodological issues of assessing the sustainable innovative development of regions, including assessing the contribution of the participants of the triad (science-education, business, government) to the overall development of the innovative economy of the region, also determine the relevance of the study.

\section{Methodology of research}

The methodology of this study is based on the author's econometric model of numerical calculations of a comparative assessment of the innovative development level of regions based on the Triple Helix model [11-12], considering the existing rating methods in Russia [13-15].

The authors propose the following methodological approach (algorithm) for assessing the level of innovation sustainability of a region based on the Triple Helix model with an assessment of the contribution of each participant in the triad of the innovation process.

At the first stage, a rating assessment of the level of region innovative development (RID) is performed based on the aggregation of groups of key indicators characterizing the innovative activities of the Triad participants. Each group of indicators includes a number of quantitative indicators, data on which are available on the official Internet resources of Rosstat, Rospatent and the Federal Treasury (Table 1).

Table 1. The system of the main indicators of the triad.

\begin{tabular}{|c|}
\hline Designation \\
\hline
\end{tabular}




\begin{tabular}{|c|c|}
\hline \multicolumn{2}{|r|}{ A - Science, education (knowledge) } \\
\hline A1 & $\begin{array}{l}\text { Number of students enrolled in undergraduate, specialist, and graduate programs per } \\
10,000 \text { people (at the beginning of the academic year), people. }\end{array}$ \\
\hline A 2 & $\begin{array}{l}\text { Share of people employed in research and development per } 10 \text { thousand of the } \\
\text { average annual number of people employed in the regional economy, \% }\end{array}$ \\
\hline A3 & $\begin{array}{l}\text { Coefficient of inventive activity per } 10,000 \text { people population (number of } \\
\text { applications for inventions and utility models), units. }\end{array}$ \\
\hline A4 & $\begin{array}{l}\text { Share of domestic expenditures on research and development in relation to gross } \\
\text { regional product (GRP), \%. }\end{array}$ \\
\hline A5 & $\begin{array}{l}\text { Number of issued patents for inventions, utility models and industrial designs per } \\
10,000 \text { labor force, units. }\end{array}$ \\
\hline \multicolumn{2}{|r|}{ B - Business (production) } \\
\hline B1 & The level of innovative activity of organizations, $\%$. \\
\hline B2 & $\begin{array}{l}\text { Share of organizations implementing technological innovations in the total number } \\
\text { of surveyed organizations, } \% \text {. }\end{array}$ \\
\hline B3 & $\begin{array}{l}\text { Share of costs for innovative activities in the total volume of goods shipped, work } \\
\text { performed, services, } \% \text {. }\end{array}$ \\
\hline B4 & $\begin{array}{l}\text { Used advanced production technologies for the Russian Federation constituent } \\
\text { entities, units. }\end{array}$ \\
\hline B5 & $\begin{array}{l}\text { The volume of innovative goods, works, services in the total volume of goods } \\
\text { shipped, works performed, services, } \% \text {. }\end{array}$ \\
\hline \multicolumn{2}{|r|}{ C - State (politics) } \\
\hline $\mathrm{C} 1$ & Share of budgetary funds in internal expenditures for research and development, $\%$. \\
\hline $\mathrm{C} 2$ & $\begin{array}{l}\text { Organizations that used electronic document management systems in the total } \\
\text { number of surveyed organizations, } \% \text {. }\end{array}$ \\
\hline $\mathrm{C} 3$ & $\begin{array}{l}\text { Number of active subscribers of fixed and mobile broadband Internet access per } 100 \\
\text { population, units. }\end{array}$ \\
\hline $\mathrm{C} 4$ & $\begin{array}{l}\text { Share of appropriations for civil science from the consolidated budget of the } \\
\text { constituent entity of the Russian Federation in the expenditures of the consolidated } \\
\text { budget of the constituent entity of the Russian Federation, \%. }\end{array}$ \\
\hline
\end{tabular}

Sources: [16-19].

Based on this system of indicators, the average values of the indicators of each region are calculated separately for blocks A, B and C for the period from 2010 to 2019, the results of which are normalized from 0 to 1 using the standard standardization methodology to bring the data to a dimensionless form, to a single range. Further, a summary table of integral indices of innovative development of regions is formed. Based on the results of the calculations, a rating is built by ranking the subjects in descending order pursuant to the value of the integral rating score for the period 2010-2019 and separately for 2019 to assess the current state.

The value of the composite integral index of the region's innovative development $\left(I_{j}\right)$ by blocks of the triad is calculated using the following formula [12]:

$$
I^{i}=\sqrt{\left(I^{\text {jsedc }}\right)^{2}+\left(I^{\text {jind }}\right)^{2}+\left(I^{\text {joov }}\right)^{2}}
$$

where:

$I_{j} S E d C$ - assessment of the impact of science and education complex on the innovative development of the $j$-th region;

$I_{j}{ }^{\text {ind }}$ - assessment of the impact of industries on the innovative development of the $j$-th region;

$I_{j}$ gov - assessment of the impact of state projects on the innovative development of the $j$-th region. 
The assessment of the contribution share of the triad participants $\left(\mathrm{C}_{\mathrm{s}}\right)$ to the general region innovative development is determined as a percentage of the composite integral index for each subject, determined by the formula:

$$
\mathrm{C}^{s}=\left(\mathrm{I}^{k} / \mathrm{I}^{j}\right)^{2} * 100 \%
$$

where $I_{k}$-the average value of the indicators of the k-th block $(\mathrm{A}, \mathrm{B}, \mathrm{C})$ of the region.

\section{Results of research}

In this work, the rating assessment of the RDI level and the assessment of the contribution of the triad participants are performed for the northern resource-type regions (NRTR) for the period 2010-2019. Resource-type regions are understood as regions characterized not only by a high resource endowment, but also by one or another degree of resource dependence. To substantiate the classification of subjects as NRTR, the authors performed calculations of the resource dependence of the regions of the Far North in the form of the share of statistical indicators for the type of economic activity "mining" (MEA) in the structure of the GRP of the subject (tab. 2), pursuant to which the following criteria for classifying an entity as resource-type regions are determined:

Highly dependent $(++)$ - over $50 \%$ of the share of MEA in the structure of the GRP of the subject.

Moderately dependent $(+)$ - from $21.4 \%$ to $50 \%$ of the share of MEA in the structure of the entity's GRP;

Independent (-) - up to $21.4 \%$ (cf. the share of MEA in the structure of the gross domestic product (GDP) of the Russian Federation) in the structure of the region's GRP.

Table 2. Resource dependence of the regions of the Far North of the Russian Federation for 2018.

\begin{tabular}{|l|r|r|r|c|}
\hline \multirow{2}{*}{$\begin{array}{c}\text { Subjects of the Far } \\
\text { North of the Russian } \\
\text { Federation }\end{array}$} & \multicolumn{2}{|c|}{$\begin{array}{c}\text { Resource dependence } \\
\text { RUR mIn. }\end{array}$} & $\begin{array}{c}\text { The volume of } \\
\text { MEA products } \\
\text { shipped, RUR } \\
\text { mIn. }\end{array}$ & $\begin{array}{c}\text { The share } \\
\text { assignment to the } \\
\text { regions of the } \\
\text { of MEA in } \\
\text { resource type } \\
\text { the share of } \\
\text { Mtructure } \\
\text { MEA }>\text { average } \\
\text { value for the } \\
\text { Russian } \\
\text { Federation) }\end{array}$ \\
\hline RF (GDP) & $84,976,724.3$ & $18,193,870$ & 21.4 & + \\
\hline Republic of Karelia & $280,012.4$ & 83,395 & 29.8 & + \\
\hline Komi Republic & $665,735.74$ & 400,373 & 60.1 & ++ \\
\hline $\begin{array}{l}\text { Arkhangelsk region, } \\
\text { including: }\end{array}$ & 819,247 & 385,402 & 47.0 & + \\
\hline $\begin{array}{l}\text { - Nenets Autonomous } \\
\text { Area }\end{array}$ & $305,213.6$ & 352,134 & 115.4 & ++ \\
\hline Murmansk region & $482,547.9$ & 96,258 & 19.9 & - \\
\hline $\begin{array}{l}\text { Tyumen region, } \\
\text { including: }\end{array}$ & $8,790,443.4$ & $6,522,593$ & 74.2 & ++ \\
\hline $\begin{array}{l}\text { - Khanty-Mansi } \\
\text { Autonomous Area - } \\
\text { Yugra }\end{array}$ & $4,447,475.7$ & $3,778,782$ & 85.0 & ++ \\
\hline $\begin{array}{l}\text { - Yamal-Nenets } \\
\text { Autonomous Area }\end{array}$ & $3,083,544.5$ & $2,470,590$ & 80.1 & ++ \\
\hline Republic of Tyva & $68,774.03$ & 28,678 & 41.7 & + \\
\hline Krasnoyarsk Krai & $2,280,025.9$ & 748,109 & 32.8 & + \\
\hline
\end{tabular}




\begin{tabular}{|l|r|r|r|c|} 
Irkutsk Region & $1,392,934.8$ & 603,873 & 43.4 & + \\
\hline $\begin{array}{l}\text { Republic of Sakha } \\
\text { (Yakutia) }\end{array}$ & $1,084,556.2$ & 804,388 & 74.2 & ++ \\
\hline Kamchatka region & $236,483.5$ & 21,518 & 9.1 & - \\
\hline Khabarovsk region & $710,639.6$ & 91,358 & 12.9 & - \\
\hline Magadan Region & $170,723.4$ & 124,937 & 73.2 & ++ \\
\hline Sakhalin Region & $1,179,668.7$ & $1,016,799$ & 86.2 & ++ \\
\hline $\begin{array}{l}\text { Chukotka Autonomous } \\
\text { Area }\end{array}$ & $78,143.4$ & 67,502 & 86.4 & ++ \\
\hline
\end{tabular}

Source: compiled by the authors based on statistical data [16].

Thus, based on the analysis of the obtained results of the resource dependence of the regions and pursuant to the criteria proposed by the authors for classifying a subject as resource-type regions, it is proposed to classify the following 8 subjects of the Far North as NRTR: Komi Republic; Nenets Autonomous Area, NAA; Khanty-Mansi Autonomous Area - Yugra, KhMAA; Yamal-Nenets Autonomous Area, YNAA; Republic of Sakha, Yakutia; Magadan Region; Sakhalin Region and Chukotka Autonomous Area, ChAA.

Pursuant to the above assessment methodology, consolidated integral ratings of the innovative development level of NRTR subjects (formula 1) were compiled, presented for illustrative convenience in a normalized form from 0 to 1 (Fig. 1).

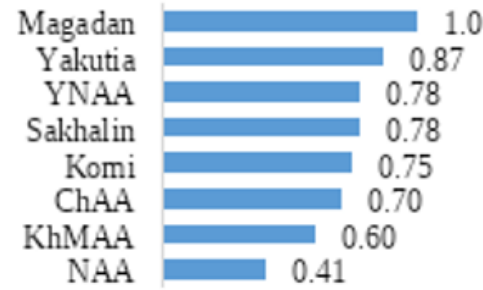

a)

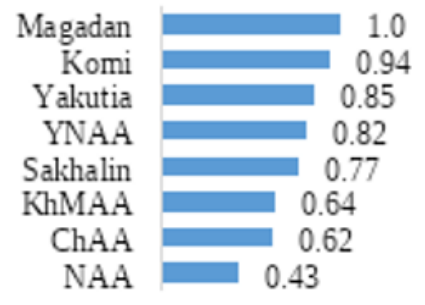

b)

Fig. 1. Rating of the integral index of innovative development of NRTR:

a) - the average value of $I_{j}$ for the period 2010-2019;

b) - the value of $I_{j}$ for 2019 .

As it follows from the presented illustration, there are some changes in the ranking positions for 2019 compared to the average value for 10 years, e.g., Komi Republic moved from the fifth position to the second position, displacing Yakutia to the third position. It should be noted that the histogram Fig. 1b reflects the current state of the comparative assessment of the innovative development level of regions for 2019.

The innovative sustainability of the NRTR may be assessed by the level of dynamics of variation of the integral index of the region's innovative development $\left(I_{j}\right)$ for the period 2010-2019 (Fig. 2). 


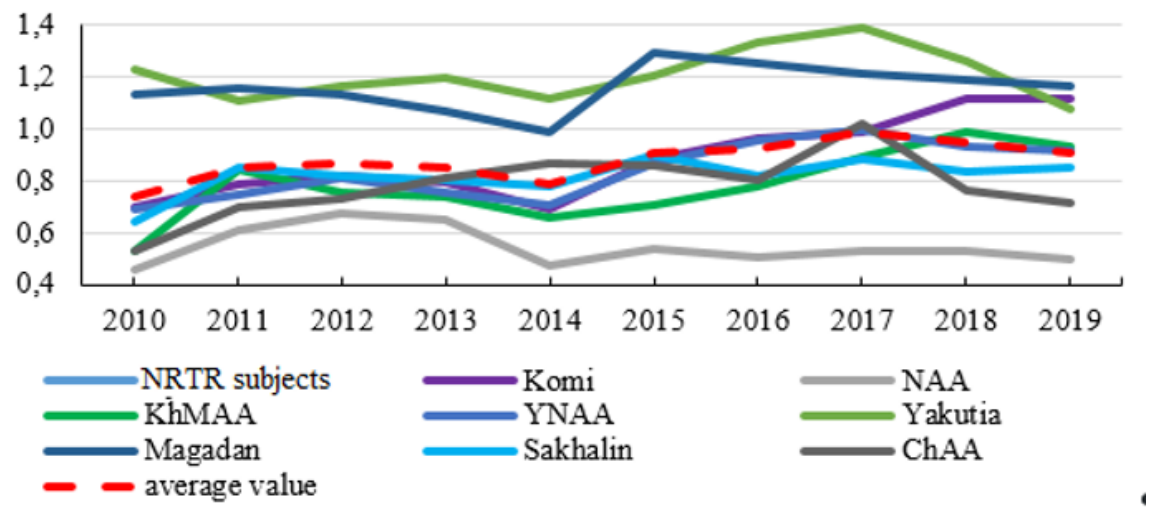

Fig. 2. Dynamics of changes in the integral index of innovative development of NRTR.

As the graph shows, in comparison with other regions, the Republic of Sakha (Yakutia) and the Magadan region have a high level of sustainability of innovative development, which have a value of $I_{j}$ higher than the average for the macroregion. The rest of the subjects of the NRTR, except for the Nenets Autonomous Area, may be attributed to regions with an average level of sustainable development of innovative activity. It should be noted that the dynamics of changes in the integral index for the participants in the triad is different, therefore, the levels of their development stability are also different. For instance, pursuant to the integral index of intellectual activity (block "Knowledge"), high indicators of development stability (above the average value for the NRTR) are shown by the Magadan Region, the Republic of Sakha (Yakutia) and the Komi Republic. In the production of innovative products (business), all regions have an average sustainability of innovative development, and the Republic of Sakha (Yakutia) is the undoubted leader in the field of promoting state policy in the development of RIS (block "Politics").

Undoubtedly, the stability of the general region innovative development's economy is influenced by the activities of the main participants in the triad separately, the degree of which is assessed on the basis of formula (2). As the calculation results show, the level of contribution (share) of each participant in the triad is different by region. The average value of the share of the influence of intellectual activity (A) on innovative development in the macro-region of the northern resource regions in 2019 is $18.8 \%$; business (B) $-34.8 \%$ and government assistance (C) - 46.4\% (Table 3). If the total amount of the share of contributions of the participants in the triad of the region $(\mathrm{A}+\mathrm{B}+\mathrm{C})$ is equal to $100 \%$, then their relatively balanced indicators should be about $33.3 \%$. The regions with such approximate indicators include the Komi Republic $(37.0 \%, 29.4 \%, 33.6 \%)$ and the Magadan Region (35.1\%, 35.1\%, 29.8\%), which caused them leading position in the rating of regions for innovative development (Fig. 1b) and, accordingly, their stability (Fig. 2).

Table 3. The level of contribution of the participants of the triad to the general region innovative development in 2019 , in percent.

\begin{tabular}{|l|r|c|c|}
\hline \multicolumn{1}{|c|}{ Subjects NRTR } & \multicolumn{1}{c|}{ A } & B & C \\
\hline Komi Republic & 37.0 & 29.4 & 33.6 \\
\hline Nenets Autonomous Area & 2.6 & 12.6 & 84.8 \\
\hline Khanty-Mansi Autonomous Area - Yugra & 18.4 & 38.8 & 42.8 \\
\hline Yamal-Nenets Autonomous Area & 9.7 & 33.2 & 57.1 \\
\hline Republic of Sakha (Yakutia) & 46.4 & 19.4 & 34.2 \\
\hline
\end{tabular}




\begin{tabular}{|l|r|r|c|} 
Magadan Region & 35.1 & 35.1 & 29.8 \\
\hline Sakhalin Region & 8.8 & 49.3 & 41.9 \\
\hline Chukotka Autonomous Area & 0.2 & 43.0 & 56.8 \\
\hline Average value by NRTR & 18.8 & 34.8 & 46.4 \\
\hline
\end{tabular}

As an example, Fig. 3 shows the histograms of the distribution of the share of the contribution of the triad participants to the overall innovative development of the four regions. In contrast to the indicators of the Magadan Region, the rest of the regions have some imbalance in the values of the participants in the triad: e.g., in Yakutia, the influence of intellectual activity prevails (A, 46.4\%) and, conversely, in the Yamal-Nenets Autonomous Area and Sakhalin Region there is a low the level of this indicator $(9.7 \%$ and $8.8 \%$, respectively). It should be noted that in regions with low intellectual potential (Nenets Autonomous Area, Yamal-Nenets Autonomous Area, Sakhalin Region, and Chukotka Autonomous Area), the contribution of the assistance of local regional authorities (C) to the development of the region's innovative economy is significantly higher than in others. regions (Table 2).

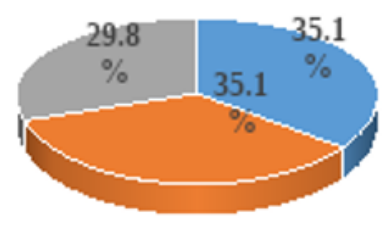

a)

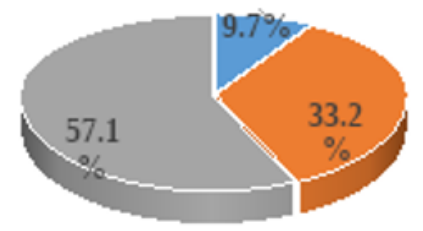

c)

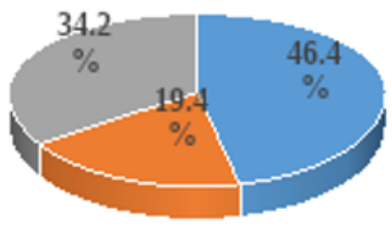

b)

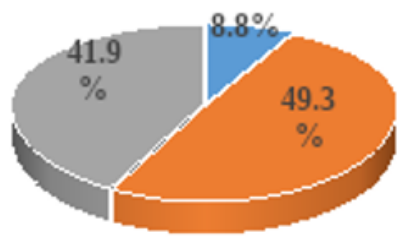

d)

Fig. 3. Histogram of the distribution of the share of the triad participants' contribution to the overall region innovative development:

a) Magadan Region; b) Yakutia; c) Yamal-Nenets Autonomous Area; d) Sakhalin Region.

For a more detailed analysis of the state of key indicators of innovative development of regions (Table 1), it is necessary to construct diagrams presented in the form of innovative profiles that allow assessing the strengths and weaknesses of the activities of the participants in the triad (Fig. 4. For instance, in the above pictures, Magadan Region has high values for 6 indicators (1) and adequately occupies a leading position among NRTR subjects. Similar innovation profiles show that regions with low rates of innovation development include Nenets and Chukotka Autonomous Areas, which are characterized by an insufficient number of innovation infrastructure facilities and a lack of structures that pursue innovation policy in these regions. 


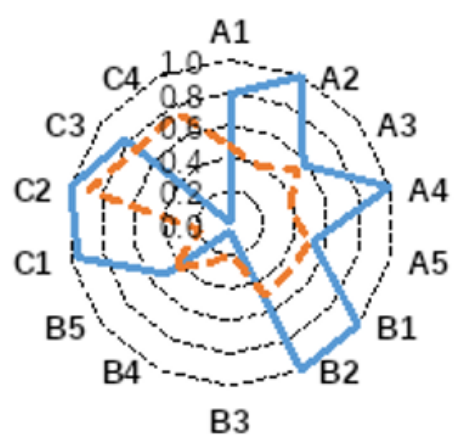

Magadan

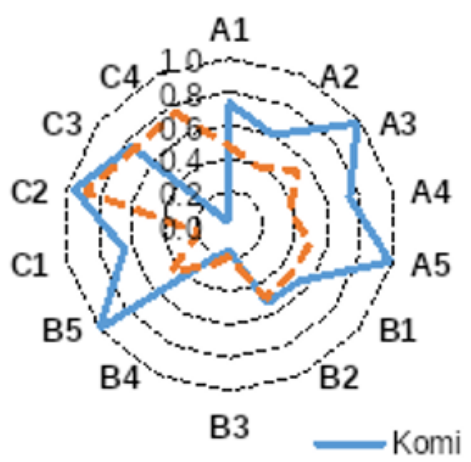



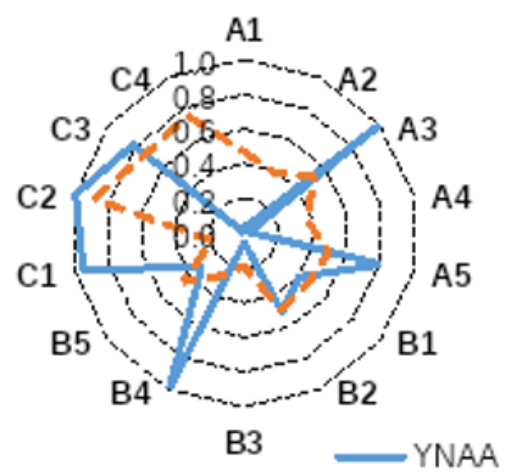

Fig. 4. Innovative profiles of regions in 2019.

In general, such a graphical representation of the state of the levels of innovation indicators allows the executive bodies of local authorities to make appropriate regulatory and managerial decisions aimed at improving the weak positions of the activities of the triad participants in order to increase the innovative component of the regional economy.

\section{Discussion of the results}

The research results obtained in this article are quite reliable, since it uses statistical data from official sources for publication in the public domain. The process of performing a quantitative assessment is performed on the basis of a system of indicators in the field of innovation, which may be adjusted depending on the goals and objectives of the study.

The authors believe that the proposed methodological approach (algorithm) based on the Triple Helix model adequately solves the assessment of the level of sustainability of the innovative development of regions and the assessment of the contribution of the Triad participants to the overall region innovative development. The main advantages of using this method include the simplicity of performing numerical calculations based on the standard Microsoft Excel platform, the use of official statistics that exclude the effect of subjectivity arising from the use of various weight coefficients.

\section{Conclusions}

Based on the selected key indicators in the innovation sphere, an integral rating assessment of the innovative development level of the northern regions of the resource type was performed for the period from 2010 to 2019. The authors propose a method for assessing 
the innovative sustainability of a region pursuant to the level of the composite integral index of the region's innovative development, calculated on the basis of the author's econometric model of the Triple Helix, which also makes it possible to determine the share of the triad participants' contribution to the overall region innovative developmental economy.

The obtained study results may be used by local executive authorities to adjust the existing regulatory documents in the field of innovation policy, as well as by various economic and social actors for monitoring and predictive assessment of the innovative development of their industry.

The research was carried out within the state assignment of the Ministry of Education and Science of the Russian Federation under projects No. FSRG-2020-0010 and No. 0297-2021-0037.

\section{References}

1. About the concept of the transition of the Russian Federation to sustainable development. Decree of the President of the Russian Federation of 01.04.1996, No. 440.

2. V. Lukyanov, O. Mukhor'yanova, S. Nedvizhai, Theoretical aspects of sustainable economic development of the region. Stavropol: AGRUS (2013)

3. M. Kalinchikov, Regional Economics: Theory and Practice 9 (24) (2005)

4. A. Bukreev, A. Pshenichnykh, Region: State and Municipal Management 2 (14) (2018)

5. Ch. Gabidullina, Economics: Yesterday, Today, Tomorrow 10, 4A (2020)

6. G. Brundtland, Report of the World Commission on Environment and Development: Our Common Future (1987). https://sustainabledevelopment.un.org/content/documents/5987our-common-future.pdf

7. Z, Badmaev, Bulletin of VSSTU 5(56), 70 (2015)

8. E. Kryukova, E. Matsui, E. Teplinskikh, Eurasian Law J. 9 (148), 447 (2020)

9. H. Etzkowitz, Soc. Sci. Information 42, 293 (2003)

10. H. Etzkowitz, L. Leydesdorff, Res. Policy 29, 2-3 (2003)

11. N. Egorov, AEBMR-Adv. in Econ. Bus. and Manag. Res. 38, 139 (2017)

12. N. Egorov, T. Pospelova, A. Yarygina, E. Klochkova, Resources 8(2), 72 (2019)

13. Rating of the socio-economic situation of the constituent entities of the Russian Federation. Results of 2019. Rating agency "RIA Rating". http://vid1.rian.ru/ig/ratings/rating_regions_2020.pdf

14. Rating of innovative development of Russian regions. https://www.nso.ru (2018)

15. Rating of innovative development of the constituent entities of the Russian Federation. https://issek.hse.ru (2020)

16. Regions of Russia. Socio-economic indicators. https://rosstat.gov.ru (2020)

17. Innovation infrastructure and the main indicators of the innovation activity of the Russian Federation. https://www.miiris.ru

18. Annual reports of Rospatent. https://rospatent.gov.ru

19. Expenditures of the consolidated budget of the constituent entities of the Russian Federation. https://roskazna.gov.ru 